\title{
TINJAUAN EKONOMI SYARIAH TERHADAP SISTEM JUAL BELI KOPI SECARA TENDER (STUDI KASUS KECAMATAN LATIMOJONG KABUPATEN LUWU)
}

\author{
Muh. Ruslan Abdullah \\ Fakultas Syariah Institut Agama Islam Negeri (IAIN) Palopo \\ Rasmawati Ilham Patintingan \\ Fakultas Ekonomi dan Bisnis Islam Institut Agama Islam Negeri (IAIN) Palopo
}

\begin{abstract}
The purpose of this study was to find out (1) the form of implementation of coffee buying and selling in tenders in Latimojong District, Luwu Regency, (2) Islamic economic views on the coffee buying and selling system in tenders in Latomojong, Luwu Regency. This research is a qualitative study using the type of social research and syar'i. Using data collection methods from literature studies (literature studies) and field research (field studies) with interview techniques directly to sellers and buyers in Latimojong District by giving specific questions about research. The results of the study revealed how to sell coffee with tenders in Latimojong Subdistrict, where sellers install prices will first use the seller using a bargaining system, after the buyer sees the Coffee location then buys a bargain at the price provided by the previous seller then bargains with willingness. Based on the Islamic economic view of the coffee buying and selling system in Latimojong Subdistrict if it is reviewed from the implementation of buying and selling based on harmony and the terms of buying and selling in accordance with Islamic Sharia regulations, because of Islamic pillars and buying conditions to buy coffee in Latimojong Subdistrict, Luwu Regency there are sellers, buyers, ijab and qabul and there are items that are traded. Not included in gharar because the quality, price, price, and time of delivery are clear.
\end{abstract}

Keywords : Buying and Selling, Tendering and Sharia Economic Review

\begin{abstract}
Abstrak
Tujuan Penelitian ini adalah untuk mengetahui (1) bentuk pelaksanaan jual beli Kopi secara tender di Kecamatan Latimojong Kabupaten Luwu, (2) pandangan ekonomi syariah terhadap sistim jual beli Kopi secara tender di Kecamatan Latomojong Kabupaten Luwu. Penelitian ini merupakan penelitian kualitatif dengan menggunakan jenis pendekatan sosial dan syar'i. Menggunakan metode pengumpulan data yakni library research (studi pustaka) dan Field research (studi lapangan) dengan teknik wawancara langsung kepada penjual dan pembeli di Kecamatan Latimojong dengan cara memberi pertanyaan yang spesifik tentang penelitian. Hasil penelitian mengemukakan bahwa pelaksanaan jual beli Kopi secara tender di Kecamatan Latimojong, dimana penjual memasang harga terlebih dahulu akan tetapi penjual menggunakan sistem tawar menawar, setelah pembeli melihat lokasi (kebun) Kopi maka pembeli menawar dengan harga yang
\end{abstract}


ditetapkan oleh si penjual sebelumnya maka terjadilah tawar menawar dengan unsur kerelaan. Adapun pandangan ekonomi syariah terhadap sistem jual beli Kopi secara tender di Kecamatan Latimojong jika ditinjau dari pelaksanaan jual beli yang berdasarkan rukun dan syarat jual beli sudah sesuai dengan tuntutan syariat Islam karena rukun dan syarat jual beli Kopi secara tender di Kecamatan Latimojong Kabupaten Luwu sudah terpenuhi seperti adanya penjual, pembeli, ijab dan qabul dan ada barang yang diperjual belikan. Serta tidak termasuk dalam unsur gharar karena kualitas, kuantitas, harga, dan waktu penyerahannya jelas.

Kata kunci : Jual beli, Tender dan Tinjauan Ekonomi Syariah

\section{PENDAHULUAN}

Secara kodrat, manusia adalah makhluk sosial yang tidak dapat hidup sendirian. Manusia selalu membutuhkan manusia yang lain, saling tergantung dan saling membutuhkan, ini merupakan sunnahtullah dan fitra manusia juga membutuhkan keperluan jasmani seperti makan, minum, pakaian, tempat tinggal dan lain sebagainya, untuk memenuhi kebutuhan, jasmaninya dia harus berhubungan dengan sesamanya dan alam sekitarnya, keadaan itu akhirnya membentuk suatu mekanisme tukar menukar antara penjual dengan pembeli, barang dan jasa yang mereka butuhkan, mempertemukan antara permintaan dengan penawaran tersebut, maka dilahirkan sistem disebut muamalah. ${ }^{1}$ Menurut Muhammad Yusuf Musa, muamalah adalah peraturan-peraturan Allah SWT., yang diikuti dan ditaati dalam hidup bermasyarakat untuk menjaga kepentingan manusia. $^{2}$

Manusia sebagai obyek hukum tidak mungkin hidup di alam ini sendiri saja, tanpa berhubungan sama sekali dengan manusia lainnya. Dalam hal ini manusia sebagai makhluk sosial sudah merupakan fitrah yang ditetapkan Allah bagi mereka dan tidak lepas dari ketergantungan dan saling berhubungan dengan makhluk lain dalam menjalani kehidupannya. Suatu hal yang paling mendasar dalam memenuhi kebutuhan seorang manusia adalah adanya interaksi sosial dengan makhluk lain yaitu hubungan dalam jual beli, maka terjadilah antara penjual dan pembeli yang sesuai dengan hukum-hukum dan syari'at Islam.

\footnotetext{
${ }^{1}$ Muhamad Nafik, Bursa Efek dan Investasi Syari' 'ah, (Jakarta : PT. Serambi Ilmu Semesta, 2009),H.89.

${ }^{2}$ Hendi Suhendi, Fiqih Muamalah, PT Raja Grafindo Persada, Jakarta: 2002, H. 2.
} 
Jual beli adalah menukar suatu barang dengan barang yang lain, menukar uang dengan barang yang diinginkan atas dasar suka sama suka sesuai dengan rukun dan syarat tertentu. Allah SWT., membolehkan jual beli yang sesuai dengan hukum Islam yang sudah ditentukan oleh Allah SWT., terjadinya berinteraksi dalam melakukan dunia usaha jual beli, bertemunya antara penjual dan pembeli yang saling berhubungan yaitu harus didasarkan dengan adanya ijab dan qobul. Ijab qobul yaitu kesepakatan antara kedua belah pihak untuk melakukan suatu yang diinginkannya.

Jual beli tindakan atau transaksi yang telah di syariahkan dalam arti telah terdapat hukumnya yang jelas dalam Islam, yang berkenaan dengan hukum Taklifi. Hukumnya adalah boleh atau kebolehannya dapat ditemukan dalam alqur'an dan sunnah Nabi SAW.,

Kecamatan Latimojong merupakan wilayah pegunungan dibagian barat Kota Belopa. Dimana tanah yang terdapat dibagian Latimojong sangatlah subur sehingga masyarakat di Kecamatan Latimojong memanfaatkan lahan yang ada untuk bercocok tanam. Di antaranya Kopi, Cengkeh, Coklat, Padi dan lain sebagainya. Tanaman Kopi merupakan tanaman yang dominan dibudidayakan, selain itu harga jual Kopi sangatlah berpengaruh pada peningkatan taraf perekonomian penduduk Latimojong.

Kecamatan Latimojong adalah penghasil Kopi terbesar dari Kota Belopa yang dikenal dengan Kopi Bisang. Penjualan Kopi di Kecematan Latimojong yang dilakukan oleh masyarakat menggunakan dua sistem jual beli yaitu jual beli secara langsung dan jual beli secara tender. Kemudian proses jual beli yang marak dilakukan akhir-akhir ini di Kecamatan Latimojong yaitu sistem jual beli secara tender. Hal ini dilakukan karena beberapa alasan diantaranya yaitu masalah jarak, waktu, tempat, dan lain-lain. Melihat fenomena ini menarik jika dikaji dari hukum Islam.

\section{METODE PENELITIAN}

Jenis penelitian yang digunakan yaitu jenis penelitian kualitatif. Penelitian kualitatif adalah tata cara penelitian yang menghasilkan data deskriptif, yaitu apa 
yang dinyatakan oleh responden secara tertulis atau lisan dengan perilaku nyata, yang diteliti dan dipelajari oleh objek penelitian yang utuh, sepanjang hal tersebut mengenai manusia atau sejarah kehidupan manusia. ${ }^{3}$ Dalam penelitian ini penulis menggunakan dua jenis pendekatan yaitu pendekatan sosial dan pendekatan syar'i. Data primer yang diperoleh dari hasil penelitian lapangan yaitu observasi dan wawancara langsung dengan para subjek penelitian jual beli Kopi secara tender di Kecamatan Latimojong Kabupaten Luwu. Data sekunder diperoleh berdasarkan jurnal, buku-buku, dan pustaka lain yang berkaitan dengan permasalahan yang sedang penulis teliti. Teknik pengumpulan data observasi, wawancara, dokumentasi

\section{PEMBAHASAN}

\section{Profil Lokasi Penelitian}

Kecamatan Latimojong adalah Kecamatan terluas di Kabupaten Luwu, luas Kecamatan Latimojong tercatat sekitar $467,75 \mathrm{~km}^{2}$ atau sekitar $15,59 \%$ dari luas Kabupaten Luwu, Kacamatan Latimojong merupakan pemekaran dari Kecamatan Basse Sangtempe pada tahun 1999 dan letak Kecamatan Latimojong itu sebelah utara berbatasan Kecamatan Basstem, sebelah timur berbatasan Kecamatan Suli barat, sebelah sealatan berbatasan Sidendeng Rappang Kabupaten Sidrap, sebelah barat berbatasan Kabupaten Enrekang dan terletak di lereng gunung Latimojong. Ketinggian Kecamatan Latimojong yang terendah dari permukaan laut kurang lebih 400 dan tertinggi dari 200 di atas puncak gunumg Latimojong. Penduduknya kurang lebih 8000 jiwa, $95 \%$ dari penduduknya adalah muslim dan $5 \%$ nonmuslim. Kecamatan Latimojong terdiri dari 12 desa yaitu Desa (Lambanan, Tibussan, Buntu Sarek, Pajang, Kadundung, Tobarru, Tolajuk, Boneposi, Ulusalu, Tabang, Pangi, Rante Balla).

\section{Jual Beli Secara Tender}

Jual beli menurut bahasa yaitu membeli sesuatu dengan imbalan sesuatu atau menukarkan sesuatu dengan sesuatu. Sedangkan menurut istilah yaitu menukarkan barang dengan barang dengan uang dengan jalan melepaskan hak

${ }^{3}$ Lexy J. Moleong, Metodologi Penelitian Kualitatif, Cet. X; (Bandung, Remaja Rosdakarya, 2005), h.3. 
milik dari seseorang terhadap orang lain atas dasar kerelaan kedua belapihak. Jadi jual beli adalah menukar suatu barang dengan barang yang lain, menukar uang dengan barang yang diinginkan atas dasar suka sama suka sesuai dengan rukun dan syarat tertentu.

Kopi adalah minuman hasil seduhan biji Kopi yang telah disangrai dan dihaluskan menjadi bubuk. Kopi merupakan salah satu komoditas di dunia yang dibudidayakan lebih dari 50 negara. Dua varietas pohon Kopi yang dikenal secara umum yaitu Kopi Robusta (Coffea canephora) dan Kopi Arabika (Coffea arabica). Kata Kopi sendiri awalnya berasal dari bahasa Arab: قهوة qahwah yang berarti kekuatan, karena pada awalnya Kopi digunakan sebagai makanan berenergi tinggi. Kata qahwah kembali mengalami perubahan menjadi kahveh yang berasal dari bahasa Turki dan kemudian berubah lagi menjadi koffie dalam bahasa Belanda. Penggunaan kata koffie segera diserap ke dalam bahasa Indonesia menjadi kata Kopi yang dikenal saat ini. ${ }^{4}$

Tender (tawaran) adalah tawaran untuk mengajukan harga, memborong atau melaksanakan suatu pekerjaan, mengadakan barang atau jasa, membeli barang atau jasa dan menjual barang atau jasa. Tender adalah suatu proses penyeleksian yang melibatkan beberapa orang.

Dengan memperhatikan definisi tersebut, pengertian tender mencakup tawaran mengajukan harga untuk:

1. Memborong atau melaksanakan suatu pekerjaan

2. Mengadakan barang atau jasa

3. Membeli barang atau jasa

4. Menjual barang atau jasa.

Adapun mengenai tender pada substansinya tidak jauh berbeda ketentuan hukumnya dari lelang karena sama-sama penawaran suatu barang/jasa untuk mendapatkan harga yang dikehendaki dengan kondisi barang/jasa sebagaimana diminati. Namun untuk mencegah adanya penyimpangan syariah dan pelanggaran

${ }^{4}$ Zul Aziz Haehaqi, Makalah Manfaat Untuk Kesehatan Prodi DIII Keperawatan Sekolah Tinggi Ilmu Kesehatan Muhammadiayah Gombong. 2012. H. 3. 
hak, norma dan etika dalam praktik tender, syariat Islam memberikan panduan dan kriteria umum sebagai guide line yaitu di antaranya:

1. Transaksi dilakukan oleh pihak yang cakap hukum atas dasar saling sukarela ('an taradhin). Sebagai mana dijelaskan dalam alquran surah Annisa'/4 : 29 "Wahai orang-orang yang beriman! Janganlah kamu saling memakan harta sesamamu dengan jalan yang batil (tidak benar), kecuali dalam perdagangan yang berlaku atas dasar suka sama suka di antara kamu dan janganlah kamu membunuh dirimu. Sungguh, Allah MahaPenyayang kepadamu". 5

2. Menurut Al-Qurtubi, at-tijarah merupakan sebutan untuk kegiatan tukar menukar barang yang di dalamnya mencakup bentuk jual beli yang dibolehkan dan memiliki tujuan. Dalam surat An-Nisa ayat 29 tersebut telah dijelaskan bahwa jual beli merupakan salah satu kegiatan yang telah dihalalkan Allah SWT., dengan syarat semua aktifitas yang dilakukan harus berlandaskan kepada rela sama rela dan bebas dari unsur riba.

3. Objek tender harus halal dan bermanfaat, seperti telah dijelaskan dalam Alquran surah Al-Baqarah/2 : 168, "Wahai manusia! Makanlah dari (makanan) yang halal dan baik yang terdapat di bumi, dan janganlah kaтu mengikut langkah-langkah setan. Sungguh, setan itu musuh yang nyata bagimu". 6

4. Kepemilikan penuh pada barang atau jasa yang dijual,

5. Kejelasan dan transparansi barang/jasa yang ditenderkan tanpa adanya manipulasi seperti window dressing atau lainnya kesanggupan penyerahan barang dari penjual,

6. Kejelasan dan kepastian harga yang disepakati tanpa berpotensi menimbulkan perselisihan

7. Tidak menggunakan cara yang menjurus kepada kolusi dan suap untuk memenangkan tender dan tawaran. 


\section{Pelaksanaan transaksi jual beli kopi secara tender di Kecamatan Latimojong Kabupaten Luwu}

Pelaksanaan tender di Kecamatan Latimojong ini tidak jauh berbeda dengan tender yang biasanya dilakukan di tempat lain hanya saja disini tender yang di Kecamatan Latimojong suatu proses pelaksanaan yang hanya melibatkan 2 orang saja di luar dari itu adalah karyawan yang petender pekerjakan untuk memetik Kopi saat panen. Kemudian disini tender di Kecamatan Latimojong itu dinamakan makborok (borongan) dan hingga sekarang di Kecamatan Latimojong ini memborong Kopi marak dilakukan dengan berbagai alasan.

1. Ilham

Ilham berusia 60 tahun bekerja sebagai seorang Petani bertempat tinggal di Dusun Doke-doke Desa Lambanan. Saat dilakukan wawancara Ilham mengatakan bahwa:

"Yatok matender makborong jaman, yatok Kopingku Kopi Arabika di paktenderkan'i ke dengmi mariri lako garontokna apa yake mararangmi namane ladi pakpeborosan lollo mangka tok buanna namane deng kesempatanna tok tau borong'i male petik'i, yake ladi baja'i biasanna yake aku nabaja undipi tau apa biasa tae kesempatanku lanekke kampong apa madada jiora bajo jama tempekku, yake carana prediksi allinna di tiro jio garontokna yake buda-buda'i jio garontokna tok Kopi di perkirakan pira lao perliter bersinna pira kotorna mane di kali pira garontok Kopi tapi kan taena pada ngasang buanna pergarontok jadi di tasserek bangmira kita tok pak baluk pada tok ladi balukanni ratu pi tok pakborok na tiro toda'i mane na tawak'i tok harga dipasang ngena enna sicocok mo hargana di benganmi na borok'i. Yamo ngena tok kupai kua madadak torro lokmora bajo jama tempekku jadi ku pakpeborosanmi tok kopingku tanggabu na dengsia tau lanjamai apa matua duka mo taeduka mo kubela'i male melako bang yaduka musim uran bang dukana marawa longsor tok lalan indek jadi matakuki male-male". ${ }^{7}$

Artinya :

Tender adalah memborong pekerjaan, Kopi yang saya miliki yaitu Kopi Arabika saya menenderkan Kopi saya saat buahnya sudah ada yang menguning dipohonnya karena kalau sudah memerah baru di petenderkan nanti buahnya jatuh baru pembeli memiliki kesempatan untuk memetiknya, kalau soal pembayaran biasanya saya dibayar di belakang

7Ilham, ' Wawancara". Penjual. Pada Hari Rabu Tanggal 08 Februari 2017. 
karena saya tidak memiliki kesempatan untuk kekampung karena saya seringnya tinggal di Bajo kerja Sawa, cara saya memprediksi harga dilihat dari buahnya kalau buahnya banyak dipohon maka diperkirakan berapa turun perliter bersihnya berapa kotornya baru kita kalikan berapa pohon Kopi tapi tidak semua buahnya sama perpohon jadi hanya ditaksir kita penjual berapa mau kita jualkan nanti kalau pemborong sudah datang melihat baru mereka menawar lagi harga yang sudah kita tetapkan tadi kalau sudah cocok dengan harga baru kita kasih untuk diborong. Itulah tadi saya bilang saya seringnya tinggal di Bajo kerja Sawa saya jadi saya menenderkan Kopi saya karena syukur alhamdulillah ada yang mau kerja karena saya juga sudah tua saya juga sudah tidak kuat pergi kesana kemari karena saat ini juga musim hujan dan tanah disini mudah longsor jadi saya takut pergi-pergi.

2. Ibrahim

Ibrahim berusia 28 tahun bekerja sebagai Guru, anak keenam dari 7 bersaudara bertempat tinggal di Desa Tibussan. Saat wawancara Ibrahim mengatakan bahwa :

"Tender menurut saya adalah menjual barang atau Kopi yang sudah matang di pohonnya yang diberikan kepada pembeli, Kopi yang saya miliki yaitu Kopi jenis Arabika kemudian cara pembayaran yang biasa saya lakukaan dengan pembeli yaitu dengan cas di bayar diawal. Dalam menentukan harga saya melihat kualitas kematangan dan banyaknya buah Kopi, biasanya Kopi bisa ditender jika buahnya sudah matang atau sudah ada sebagian buahnya yang menguning perkiraan 4 bulanan. Bukan lebih memilih menjual secara tender akan tetapi tender memberikan kemudahan dan juga keuntungan bagi saya karena dengan tender saya tidak repot lagi melakukan panen, karena yang memetik langsung adalah pihak pembeli dan keuntungan yang lebih, saya dapat memperoleh uang dari hasil penjualan Kopi secara tender dengan cepat, kemudian kalau mengajarkan mulai pagi jam 07:30-13:00 sampai sabtu saat pulang mengajar istirahat jadi tidak ada kesempatan untuk memetik Kopi". ${ }^{8}$

\section{Nasrul}

Nasruh berusia 45 tahun bekerja sebagai Petani sekaligus Pembeli bertempat tinggal di Desa Buntu Sarek. Menurut Nasrul selaku pakborok (petender) di desa Tibussan mengatakan bahwa:

"Tender itu membeli/menjual barang secara borongan pelaksanaan tender yang saya lakukan yaitu ketika ada berita-berita burung bahwa sibecce menenderkan Kopinya sekian, saya langsung bergegas ketemu dengan sibecce dan langsung meninjau lokasi atau kebun Kopinya setelah

\footnotetext{
${ }^{8}$ Ibrahim, ”Wawancara”. Penjual. Pada Hari Minggu Tanggal 05 Februari 2017.
} 
meninjau buah Kopinya dan memperkirakan harga, disitulah kami tawar menawar harga sampai ada kesepakatan di antara kami. Kopi yang biasa saya tender yaitu Kopi Arabika karena Kopi yang banyak dibudidayakan oleh masyarakat di Kecamatan Latimojong sekarang itu adalah Kopi Arabika. Dalam menyikapi kerugian yang terjadi kami hanya pasra ketika terjadi kerugian tapi disini ketika berbicara kerugian kami rasa tidak akan terjadi kerugian ketika kita sudah memetik Kopinya langsung dijual jangan terlalu menunggu harga tinggi karena biasanya Kopi itu busuk atau kempes sendiri ketika tinggal lama". ${ }^{9}$

4. Ahmat

Ahmat brusia 48 tahun bekeja sebagai Petani sekaligus Pembeli bertempat tinggal di Desa Tibussan. Dari hasil wawancara menurut Ahmat selaku petender kopi di Desa Tibussan mengatakan bahwa:

"Tender keindek kampong disanga makborok jadi tender itu makborok Kopinna tau dialli na di jakarang pangjama napetikkanki.Yake makborokna biasanna taunna tentukan hargana mane maleditiro belakna toklana pakpeborosan yake pada sicocok hargamo manemi dibajak allinna apa yake taepi doi sorokpi makpetik namane dibajak yaraka dibajak penduanni, yato Kopi madadaku boroktok Kopi Arabika. Yake rupangki kerugian harus iya ditarima na buak pirakaia ke rugi toda miki ia tapi kan ditandai toda mia keladi borok'i tok Kopi kua pada tok bisa kulolongan jadi sorok memang mia diperkirakan apa ditiro langsung ia tok buanna tok Kopi". 10

Artinya :

Tender kalau disini kampung dinamakan makborok (memborong) jadi tender itu memborong Kopi seseorang kemudian dibeli lalu dicarikan pekerja untuk memetiknya. Kalau memborong biasanya yang menentukan harga itu orang yang memiliki Kopi kemudian kita pergi melihat lokasi Kopi yang mereka jual kalau sudah cocok harga baru dibayar harganya tapi kalau belum ada uang nanti setelah memetik baru dibayar atau dibayar duakali, kalau Kopi yang biasa saya beli Kopi Arabika. Kalau kita dapat kerugian harus kita terimah mau bagaimana kalau sudah rugi tapikan pada saat kita membeli Kopi itu kita sudah menaksirkan begini harga yang saya dapatkan nantinya karena kita sudah melihat langsung Kopinya.

Dari hasil wawancara di atas dapat disimpulkan bahwa pelaksanaan jual beli Kopi secara tender di Kecamatan Latimojong di sebabkan beberapa alasan yaitu di antaranya ada yang mengatakan dirinya sudah tua sehingga tidak kuat

\footnotetext{
9Nasrul, ”Wawancara”.Pembeli.Pada Hari Kamis Tanggal 09 Februari 2017.

${ }^{10}$ Rahmat, “Wawancara”. Pembeli.Pada Hari Kamis Tanggal 02 Februari 2017.
} 
lagi untuk memetik Kopinya, ada yang mengatakan bahwa mereka sudah membutuhkan uang segara sehingga mereka menenderkan Kopinya, ada juga yang sudah diluar daerah tidak sempat lagi pulang karena berbagai kesibukan, dan ada yang memiliki kebun yang banyak dan tidak memiliki anak dan keluarga yang banyak sehingga tidak bisa memetiknya dalam waktu bersamaan, kemudian ada yang memiliki pekerjaan lain seperti (Bidan, Guru, Wiraswasta) sehingga mereka tidak memiliki waktu untuk memetik Kopi mereka, serta ada juga yang mengatakan bahwa kita bisa menciptakan lapangan pekerjaan bagi orang lain yang tidak memiliki pekerjaan.

Sedangkan dalam praktek jual beli Kopi secara tender ini dilakukan dengan cara saat buah Kopi sudah matang atau sudah ada sebagian buahnya yang menguning dan memerah para petani memperkirakan (menaksirkan) harga dengan cara memprediksi hasil buah Kopi tersebut perpohon kemudian mengalihkannya dengan jumlah pohon Kopi yang ada atau membandingkan hasil dengan tahun sebelumnya kemudian dikalikan harga Kopi saat yang sama. Kemudian petani memberikan kabar kepada masyarakat bahwa kopinya di tenderkan sekian dan dari mulut kemulut sehingga sampailah kabar ini kepada pembeli (petender) Kopi kemudian datanglah pembeli kerumah si petani dan mereka langsung meninjau lokasi atau kebun Kopi si petani yang akan ditender Kopinya.

Setelah petender melihat lokasi atau kebun dan melihat keadaan buah Kopi yang akan dibelinya maka petender menawar kepada pihak petani dari harga yang sudah ditentukan oleh petani sebelumnya disitulah mereka saling tawar menawar harga Kopi yang akan ditender sehingga terjadi kepakatan di antara mereka. Setelah itu antara petender dan petani melakukan transaksi pembayaran. Proses pembayaran jual beli Kopi secara tender yang disepakati di Latimojong ada tiga yaitu dengan cara pertama dibayar sebelum dipetik, kedua setelah dipetik baru dibayar, ketiga sebagian dibayar dimuka dan sisanya dibayar setelah panen.

Dalam hukum jual beli secara tender atua borongan (tebas) Para Ulama sepakat atas bolehnya jual beli secara borongan atau taksiran. Berdasarkan hadits, 


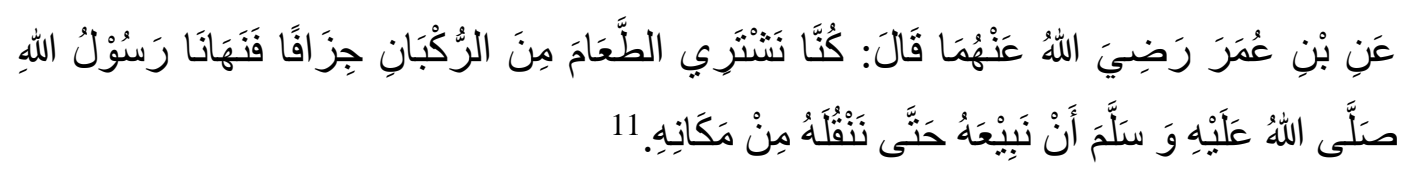

Terjemahnya:

Dari Abdullah bin Umar, dia berkata, "Dahulu kami (para sahabat) membeli makanan secara taksiran, maka Rasulullah melarang kami menjual lagi sampai kami memindahkannya dari tempat belinya." (HR. Muslim: 1526)

Makna dari جَزَافِ adalah jual-beli makanan tanpa ditakar, ditimbang, dan tanpa ukuran tertentu. Akan tetapi menggunakan sistem taksiran, dan inilah makna jual-beli borongan. Sisi pengambilan hukum dari hadits ini, adalah bahwa jual beli sistem borongan itu merupakan salah satu sistem jual beli yang dilakukan oleh para sahabat pada zaman Rasulullah SAW dan beliau tidak melarangnya. Hanya saja, beliau melarang untuk menjualnya kembali sampai memindahkannya dari tempat semula. Ini merupakan taqriri (persetujuan) beliau atas bolehnya jual beli sistem tersebut. Seandainya terlarang, pasti Rasulullah SAW akan melarangnya dan tidak hanya menyatakan hal di atas.

Al-Hafizh Ibnu Hajar berkata, "Hadits ini menunjukkan bahwa jual-beli makanan dengan sistem taksiran, hukumnya boleh.” (Fathul Bari: 4351). Imam Ibnu Qudamah berkata, "Kami tidak mengetahui adanya perselisihan dalam masalah ini." (Lihat pula Mausu'ah al-Manahi Syar'iyyah oleh Syekh Salim alHilali 2/233).

Transaksi dikatakan tidak Islami bila tidak memenuhi syarat yang ditetapkan dalam fiqh dan terdapat pula larangan Nabi Muhammad SAW dan oleh karena itu hukumnya haram. Praktek transaksi ini telah berlangsung dikalangan arab sebelum mereka masuk di antaranya, dalam praktek jual beli jeruk ini dilakukan pada saat buah jeruk masih kecil atau muda yang masih berada di pohonnya, maka dalam hukum Islam jual belinya tetap sah tetapi melakukan transaksi jual beli secara tebasan buah jeruk yang masih di pohon, dalam hal ini 243.

${ }^{11}$ Mashur Khar. Bulughul Maram Buku Pertama. (Jakarta: PT Rineka Cipta. 1992), h. 
ditakutkan adanya kerusakan dan terserangnya penyakit pada buah jeruk yang belum saatnya panen maka bisa menjadi jual beli gharar. Apabila buah-buahan di jual sebelum tampak kualiatasnya dan tanaman sebelum tua, maka jual beli hukumnya sah dengan syarat dipetik pada saat akad dan jika ada kemungkinan memanfaatkannya walau belum dipetik. Karena hal seperti itu tidak dikhawatirkan akan terjadi kerusakan dan serangan hama yang merusak.

Jual beli tender buah Kopi dengan cara tender di Latimojong ini merupakan jual beli barang yang jelas kadarnya karena buahnya sudah matang sudah ada sebagian buahnya yang menguning meski masih ada sebagian yang masih hijau (mudah) karena buah Kopi ini tidak hanya sekali panen ada yang 3-5 kali panen. Jual beli ini tidak termasuk jual beli yang dilarang karena sudah memenuhi syarat dan rukunnya.

Menurut Maliki, Syafi'i, dan Hambali jika seseorang menjual buah-buahan sesudah nyata baiknya, hukumnya adalah boleh sedangkan menurut Hanafi: tidak boleh menjualnya dengan syarat tidak dipetik segera. ${ }^{12}$

\section{PENUTUP}

\section{Kesimpulan}

Berdasarkan rumusan masalah dan hasil penelitian peneliti menarik kesimpulan sebagai berikut :

a.Pelaksanaan jual beli Kopi secara tender di Kecamatan Latimojong yaitu pengusaha lokal terlebih dahulu melihat langsung kebun Kopi dengan menganalisa jumlah kira-kira secara kotor sekaligus analisa tenaga kerja yang akan dibutuhkan dan membandingkan harga Kopi dari tahun ketahun setelah itu pihak pengusaha mengajuan penawaran dari harga yang sudah ditentukan oleh penjual sebelumnya. Sistem pembayaran yang disepakati ada 3 yaitu yang pertama dibayar sebelum dipetik, kedua setelah dipetik, ketiga dibayar dimuka dan sisanya dibayar setelah panen. Sebelum terjadi tender ada musyarah mufakat yang dilandasi oleh sifat kekeluargaan dan sifat kejujuran oleh kedua belah pihak dimana

${ }^{12}$ Syaikh al-'Allamah Muhammad bin Abdurrahman ad-Dimasyqi, Fiqhi Empat Mazhab (Hasyimi press 2001).h. 234. 
kedua belah pihak secara bersama-sama membahas kemungkinan hasil dari kebun dan harga kopi pada saat paska panen.

b. Tinjauan ekonomi syariah terhadap jual beli Kopi secara tender yang dilakukan oleh masyarakat Kecamatan Latimojong sah menurut syariah karena kualitas, kuantitas, harga, dan waktu penyerahannya jelas tidak mengandung unsure gharar serta rukun dan syaratnya sudah terpenuhi seperti adanya penjual, pembeli, ijab dan qabul dan ada barang yang berlaku dengan kerelaan dan suka sama suka diantara mereka.

\section{Saran}

a.Penjual ataupun pembeli di Kecamatan Latimojong lebih meningkatkan pemahaman tentang jual beli dalam Islam.

b. Kepada masyarakat Latimojong khususnya untuk pembeli jangan sampai melakukan kecurangan kepada masyarakat ketika melakukan jual beli tender Kopi. Begitupun dengan penjual jangan terlalu memasang harga terlalu tinggi saat menenderkan Kopinya.

c. Bagi penjual jangan terlalu berlebihan mencari keuntungan dan bagi pembeli jika mendapat keuntungan lebih besar dari yang ditender sebaiknya mengembalikan sebagian keuntungan itu kepada si penjual.

\section{DAFTAR PUSTAKA}

Al-quran Al-Karim

Al-Imran Zainudin Ahmad bin Abdullah Lathif Az-Zabidi, Shahih Al-Bukhari Bandung : Mizan, 1997.

Dr. Mardani, Fiqh Ekonomi Syariah, Jakarta : Kharisma Putra Utama. 2013.

Elvi Hardianti, Pengaruh Harga Jual Beli Jopi Terhadap Tingkat Kesejahteraan Petani Didesa Ulusalu Kecamatan Latimojong, Jurusan Ekonomi, Institut Agama Islam Negeri Palopo,2016.

Haehaqi Zul Aziz, Makalah Manfaat Untuk Kesehatan Prodi DIII Keperawatan Sekolah Tinggi Ilmu Kesehatan Muhammadiayah Gombong. 2012.

Hamid AT., Ketentuan Fiqh dan Ketentuan Hukum Yang Kini Berlaku di Lapangan Hukum Perkanan, Surabaya: PT Bina Ilmu, 1983.

Haroen Nasrun, Fiqih Muamalah, Gaya Media Pratama, Jakarta: 2007. 
Kamus Besar Bahasa Indonesia, Ed. Ketiga Jakarta: Balai Pustaka, 2002.

Mashur Khar. Bulughul Maram Buku Pertama. Jakarta: PT Rineka Cipta. 1992.

Mengah asyah fuferti, Syakbaniah, dan Ratnawulan, Perbandingan Karakteristik Fisis Kopi Luwak (Civet coffee) dan Kopi Biasa Jenis Arabika, Jurusan Fisika, Universitas Negeri Pandang.2013.

Moleong J Lexy, Metodologi Penelitian Kualitatif, Cet. X; Bandung, Remaja Rosdakarya, 2005.

Mohd Ma'sum Billah, Penerapan Hukum Dagang Dan Keuangan Islam, Jakarta: PT. Multazam Mitra Prima 2009.

Muhammad Nasirudin al-Albani, Sunan Ibn Majjah, Penerjemah Ahmad Taufiq Abdurrahman, jilid 2, Jakarta: Pustaka Azzam, 2007.

Nafik Muhamad, Bursa Efek dan Investasi Syari"'ah, Jakarta : PT. Serambi Ilmu Semesta, 2009.

Niazi Liaqueat Ali Khan, Islamic Law Of ContractLahore: Research Cell, Dyal Singh Trust Library, 1990.

Non-Medicinal Plants and T.K. Lim. Edible Medicinal, Volume 5, Fruits. Springer Science, 2013.

Rachmat syafei, Fiqih Muamalah, Edisi Ke 3 (Tiga) Bandung : Pustaka Setia, 2006.

Rasjid Sulaiman, Fiqih Islam, Bandung: Sinar Baru Algensindo, 1986.

Sudarsono, Kamus Hukum Jakarta: PT. Asdi Mahasatya, 2007.

Suhendi Hendi, Fiqih Muamalah, PT Raja Grafindo Persada, Jakarta: 2008.

Suherman A. Sherly, Tips Jitu Menang Tender Menjadi Pemenang Sebelum Tender Dimulai,Jakarta: PT. Buku kita, 2010.

Syarifuddin Amir, Garis-garis Besar Fiqhi Islam, Jakarta : Granada Media Group, 2005.

Syafe'i Rachmat, Fiqhi Muamalah, Bandung : CV Pustaka setia.2001.

Syaikh al-'Allamah Muhammad bin Abdurrahman ad-Dimasyqi, Fiqhi Empat Mazhab, Hasyimi press 2001.

Abdul Mujib, Makalah Bai Macam dan Hukumnya: Murabahah, Muzayadah, Mu naqashah\#.Vfkpu30sfDcDiakses pada tanggal 16 Juli 2016 pukul 15:17. 
Nabilah Imani, Makalah KopiWww.Academia.Edu/18119895/Makalah_Kopi Di Akses Pada 24 November 2016.

Fattih, Rima, “Kopi”'Http://Digilib.Unimis.Ac.Id/Files/Disk/139/Jtptunimus-GdlFattihrima-6918-3-Babii.Pdf (Diakses Pada Tanggal 25 November 2016)

Jurnal Bumi, Sejarah Kopi Https//Jurnalbumi.Com/sejarah-Kopi/ (Di Akses Pada 24 November 2016)

Liaqueat Ali Khan Niazi, Islamic Law Of Contract (Lahore: Research Cell, Dyal Singh Trust Library, 1990) H.124. 